\title{
IMPROVING LABOR MARKET AS A STRATEGIC FACTOR IN ECONOMIC GROWTH
}

\begin{abstract}
The article focuses on the labor market of the Ukraine and the meaning of human resources for economic growth.

The article deals with the effect of unemployment, which in the Ukraine is not only part of the market economy, but also the result of specific political and economic factors. The article deals with the content of research labor market on the brink of social, economic and psychological aspects. Proposed methodology which applied to determine the emotional state of the individual and the model of monetary panic on the coverage of mental and emotional mood of social groups or society as a whole. With increasing polarization in society is an urgent social justice and protection of the population and the demand for labor as the main source of income is the primary desire and goal at a time. According to the duality theory of mathematical programming (as a way of balancing the relationship between employers and workers), improving the labor market is a priority task, because according to parameters of official salary and assessment of professional knowledge and skills mathematical problem has not the solution, has no common points. Therefore the national economy should be developed according to economic laws, in spite of existing imbalances in the national economy, the people of the Ukraine deserve adequate assessment of their knowledge and skills and, therefore, have possibility to exercise their moral and material needs. Proved that the most important measure of social-economic policy of Ukraine is the formation of a qualitatively new economy, the basis of which is the humane, rational, efficient use of labor resources.
\end{abstract}

Keywords: economics, increase, labour force, duality theory.

\section{RAISING THE QUESTION}

Economic growth is the main indicator of development and prosperity of any country, one of the chief macroeconomic objectives. It is essential to achieve accelerated growth of national income compared to the amount of population.

Socio-labour relations are the cornerstone of the entire system of relations in the society. Improving utilization of human resources is of strategic importance for further development of the global and national economies.

The labour market is the most difficult element of the market economy, which not only links the interests of workers and employers in price for the services provided and working conditions, but also shows the socio-economic changes. The labour market performs both general and specific functions, presents the correlation between supply and demand of labour force and reflects current state of affairs in the industry.

\footnotetext{
${ }^{1}$ Associate professor of the Department of Economic Cybernetics, Faculty of Computer Sciences and Economic Cybernetics, National University of Life and Environmental Sciences of Ukraine, Kyiv, Heroiv Oborony Str., 10a, Room 112, e-mail: poprozman@ukr.net
} 
Thus, the concept of human development is based on inability to make social progress equal to growing income: economy exists for people's development, and not vice versa ${ }^{2}$.

The aim of the article is to study the problems of formation of the national labour market and of harmonization of socio-labour relations.

\section{ANALYSIS OF RECENT RESEARCH AND PUBLICATIONS}

The issue of labour force has always been of great interest among national and foreign scientists. The following researchers paid their attention to this problem: S. Bandur, V. Geyets, V. Inozemtsev, V. Goyko, A. Klepach, A. Kolot, Yu.Krasnov, B. Danylyshyn, L. Pashko, B. Bilobrova, V. Vasylchenko, S. Zlupko, B. Paskhaver, D. Bogynya, V. Kutsenko, L. Semiv, E. Libanova, S. Pyrozhkova, I. Petrova and others.

However, despite the significant achievements of scientists in the study of this topic, it still requires further research because of its extreme complexity.

\section{UNSOLVED ASPECTS OF THE PROBLEM}

The twenty-first century is the century of the information society, which implies increasing importance of science, education, information, innovative technologies, and human intelligence in general that is highly marketable and, therefore, has a number of specific properties. This non-material product creates a material basis of economic activity and serves as an important factor for economic growth.

However, often the ideas generated in Ukraine are not put into practice in this country and, therefore, benefit some other foreign economy instead of the national one.

\section{THE RESEARCH RESULTS}

The state of socio-labour relations is influenced by the unemployment rate, which is a component of the market economy and is one of its negative consequences. It should be noted that the unemployment rate in the Ukraine is lower than in the European Union, where in the $1^{\text {st }}$ quarter of 2013 the average unemployment rate amounted to $11 \%$, in particular, in Greece and Spain $-27 \%$, in Croatia and Portugal - 18\%, Ireland - 14\%, Latvia $-12 \%^{3}$. Youth unemployment is one of the most acute problems as its rate is the highest as compared to the rate among other age groups, although this is a global tendency as well. Moreover, the process of employment of young specialists requires significant improvement.

High unemployment rate causes increased socio-economic stratification, lower income, deskilling of the labour force, under-utilization of manpower, which, in turn, means a loss of potential production of goods and services, psychological trauma and social conflicts. Vacant positions, existing along with unemployment, not only reflect underutilization of labour force, but also show irrational utilization of the main means of production. There are numerous reasons that cause this situation, among them low salaries for these vacancies, poor working conditions, high intensity of work, imbalance between

\footnotetext{
${ }^{2}$ The concept of humanitarian development of Ukraine for the period until 2020 (2011), available at: https //docs.google/ com/viewe?url=http//www.kultura.pl.ua/images/doks/koncepciya_hum_rozvytku.pdf.

${ }^{3}$ M.V. Lazebna, Quality of employment of people should be in the first place, "Rynok pratsi ta zajniatist' naselennia" 2013/3, p. 3.
} 
demand and supply of jobs, which results in significant economic and social distortions and losses ${ }^{4}$.

The complex study of economic, social and psychological aspects of the labour market is extremely important and topical.

When making effective decisions agents of the market economy pay more and more attention to the emotional component of an individual, which sometimes can form the opinion of not only a separate specialist, but of a certain social group.

Mental and emotional aspects and their impact on labour productivity are investigated by many scientists, including V. Vitlinskyy ${ }^{5}$, who indicates the existence of problems related to internal and external adjustments of individuals to risks.

Thus, external adjustment to risk (introversion) lies in an attempt to modify external conditions, whilst internal adjustment to risk (extraversion) is characteristic of those individuals, who do not believe in control over external circumstances or in the possibility to influence them.

Stress caused by unemployment can result in a life crisis (it has been proved that everyone has a predisposition to it), but attitude to this situation varies depending on individual, inherited or acquired, internal resources ${ }^{6}$.

Psychological tests show that the level of stress caused by a job loss is the same as the level of stress caused by the death of a dear person ${ }^{7}$.

This approach helps to distinguish a vector of individual condition, which provides quantitative assessment of the state of an individual in a given period of time defined by a new event that changes the coordinates of the vector.

The vector of individual condition (VIC) contains values of emotional and rational individual experience. Coordinates of the vector are $\mathbf{n}$ elements that show positive emotions at this exact moment (or those saved in memory), $\mathbf{m}$ elements that denote negative emotions, $\mathbf{p}$ element that stands for rationality corresponding to the existing practical experience about a changing event and $\mathbf{h}$ element that defines theoretical knowledge of this individual $^{8}$.

Thus, the vector of individual condition of a person taking a decision is as follows:

$\mathrm{VIC}=\left(\mathrm{e}_{\mathrm{o} 1}, \mathrm{e}_{\mathrm{o} 2}, \ldots, \mathrm{e}_{\mathrm{on}}, \mathrm{e}_{\mathrm{p} 1}, \mathrm{e}_{\mathrm{p} 2}, \ldots, \mathrm{e}_{\mathrm{pm}}, \mathrm{e}_{\mathrm{p}}, \mathrm{e}_{\mathrm{h}}\right)$,

where the first $\mathbf{n}$ elements of the vector and the last two elements take values 0 or 1 depending on the availability of this emotion now or in memory, the following $\mathbf{m}$ elements may take values $0,-1,-2$, depending on the degree of negative emotions. The dif-

\footnotetext{
${ }^{4}$ A.M. Kolot, Sotsial'no-trudova sfera: stan vidnosyn, novi vyklyky, tendentsii rozvytku [Socio-labour sector: the state of relations, challenges and trends], Kyivs'kyj Natsional'nyj ekonomichnyy universytet im. V.Het'mana, Kyiv 2010,p. 45; L.M. Yemel'ianenko, Sotsial'no-ekonomichni dominanty liuds'koho i tekhnolohichnoho rozvytku Ukrainy [Social and economic dominants of human and technological development of Ukraine], NAN Ukrainy, Kyiv 2009, p. 34.

${ }^{5}$ V.V. Vitlins'kyj, P.I. Verchenko, Analiz, modeliuvannia ta upravlinnia ekonomichnym ryzykom [Analysis, modelling and management of economic risk], KNEU, Kyiv 2000, p. 12.

${ }^{6}$ T.M. Tytarenko, Zhyttievyj svit osobystosti u mezhakh $i$ za mezhamy budennosti [The life of an individual within and beyond ordinary], Lybid', Kyiv 2003, p. 56.

${ }^{7}$ I.M. Liashenko, I.M. Korobova, I.A. Horitsyna, Modeliuvannia ekonomichnykh, ekolohichnykh i sotsial'nykh protsesiv [Modelling of economic, environmental and social processes], Vydavnycho-polihrafichnyj tsentr „Kyivs'kyj universytet”, Kyiv 2010, p. 163.

${ }^{8}$ N.V. Apatova, Formation of the vector of individual condition of an economic agent, "Sbornik nauchnikh trudov V Mezhdunarodnoj shkoly-simpoziuma AMUR” 2011, TNU im. V.I.Vernadskogo, Ukraine, p. 16.
} 
ference in the range of positive and negative emotions can be even larger, which is explained by the fact that negative emotions are stronger and stay for a longer period of time in the memory of an individual. Leading psychologists state that negative emotions remain in the memory 3-4 times longer that the positive ones (ratio 80/20).

The methodology shows that the sum of coordinates of the vector of individual condition is the actual state of an individual at a given moment of time. It is obvious that as soon as an individual receives new external signals, the quantitative assessment of the vector will change and will serve as the characteristics of the individual under given circumstances for the corresponding period of time.

It should be mentioned that the psycho-emotional state of the population is always taken into account when creating the model of currency panic.

Panic is characterized as an avalanche, chain process. In socio-economic terms this effect on population can be caused by exchange panic, advertising, sales, state of affairs at the real estate market or market of precious metals, elections, revolutions etc.

As for the model of currency panic, let us assume that the amount of money owners is big. We can say that people willing to change the money to currency are 'contaminated' with a panic virus, if they communicate their desire to exchange money to other money owners who can be 'contaminated' or 'uncontaminated'. The downside of this approach is multiple records of people who were 'contaminated' several times because they got messages from other individuals at the same time".

This approach provides an opportunity to efficiently tackle the issue of mood changes in the social groups, relieve social tension of the population and achieve harmonious microclimate in the company. It will not only improve the quality of decision-making, but also will affect moral satisfaction the employees receive from their work, and hence increase productivity and allow performing more accurate socio-economic forecasts for growth and development of the economic system.

Work is considered to be ideal when it brings moral and material fulfilment of human needs, but if it doesn't, it can cause discomfort, depression or social tension among the staff or the society as a whole. It should be noted that the issue of harmonization of relations between employers and workers is the most difficult issue at the labour market and in the society in general.

From 2001 to 2012 the number of religious organizations increased from 24311 to 34586 , in addition, there were approximately 1914 unregistered religious organizations ${ }^{10}$. Respect and tolerance serve as the basis for healthy microclimate and diligent attitude to work. However, there is a thought that the amount of such organisations is also dependent on the socio-economic decrease of living standards.

Key aspects of quality of life include economic, social, political, demographic and intellectual development of the country.

Rising unemployment makes the poverty issue more acute, and, therefore, the role of social policy as a set of social and economic activities aimed at overall development of

\footnotetext{
${ }^{9}$ T.S. Klebanova, N.A. Dubrovina, O.J. Poljakova, Modelirovanie jekonomicheskoj dinamiki [Modelling of economic dynamics], 2 ed., Izdatel'skij dom „INZhJeK”, Kharkiv 2005, p. 35.

${ }^{10}$ Statistical Yearbook of Ukraine for 2012, Kyiv 2013, p. 56.
} 
people and insuring appropriate quality of life, social justice and protection significantly increases ${ }^{11}$.

Human development is treated as a criterion of social progress, as a means of increasing income, and is valuable only then when it really impacts people's welfare ${ }^{12}$.

The demand for labour as the chief source of income and the labour supply affect the amount of income received as wages or salaries. So the main issue under discussion between a worker and an employer is a price for some amount of work to be done. This price defines both the income the worker will obtain and the cost the employer will pay for the work.

Such duality can also be observed in the fact that a person is a manufacturer of all material goods and services and simultaneously a consumer of these goods and services. Depending on the above given definitions, it can be stated that humanization should be the basis for labour relations, but in fact it is not always so.

Using the duality theory (the relations between workers and employers are of dual nature) allows to produce the following mathematic task:

$$
\begin{aligned}
& Z=c_{1} x_{1}+c_{2} x_{2}+c_{3} x_{3}+\ldots+c_{n} x_{n} \rightarrow \max \\
& a_{11} x_{1}+a_{12} x_{2}+a_{13} x_{3}+\ldots+a_{1 n} x_{n} \leq b_{1} \\
& a_{21} x_{1}+a_{22} x_{2}+a_{23} x_{3}+\ldots+a_{2 n} x_{n} \leq b_{2} \\
& a_{m 1} x_{1}+a_{m 2} x_{2}+a_{m 3} x_{3}+\ldots+a_{m n} x_{n} \leq b_{m} \\
& x_{j} \geq 0, j=1 ; 2 ; n,
\end{aligned}
$$

where $\mathrm{x}_{1 \ldots \mathrm{n}}$ - amount of the work of i-type done, units;

$c_{1 \ldots . n}-$ wage/salary for the completed amount of work of i-type, currency units; $\mathrm{a}_{\mathrm{ij}}$ - time for completing the work of i-type, hours;

$b_{i m}-$ total amount of time for completing the work of i-type, hours.

Let us consider another task. Let us suppose that there is an employer that wants to hire manpower for satisfying the needs of his enterprise and who has a sufficient amount of material resources and money. Both the employer and the worker face the question about the amount of money the employer is willing to pay and the worker wants to obtain. If we denote the price of a corresponding labour unit as $y_{i}$, then the employer's task is to minimize costs for engaging manpower. However, the employee will agree to perform the task only if the amount of money received for carrying out professional activities is not

\footnotetext{
${ }^{11}$ O.V. Zhadan, Sotsial'no-trudovi vidnosyny v umovakh hlobalizatsii: teoriia i praktyka derzhavnoho rehuliuvannia [Socio-labour relations in the context of globalization: theory and practice of state regulation], Natsional'na akademija derzhavnoho upravlinnja pry Prezydentovi Ukrainy, Kharkivs'kyj rehional'nyj instytut derzhavnoho upravlinnia, Kharkiv 2012, p. 35.

${ }^{12}$ E.M. Libanova, E.M. Palij, Rynok pratsi ta sotsial'nyj zakhyst [Labour market and social security], Osnovy, Kyiv 2004, p. 11.
} 
less than the amount of the expected income gained by hourly work or/and running own business. The mathematical form of this problem looks as follows:

$$
\begin{gathered}
W=b_{1} y_{1}+b_{2} y_{2}+b_{3} y_{3}+\ldots+b_{m} y_{m} \rightarrow \min \\
a_{11} y_{1}+a_{21} y_{2}+a_{31} y_{3}+\ldots+a_{m 1} y_{m} \geq c_{1} \\
a_{12} y_{1}+a_{22} y_{2}+a_{32} y_{3}+\ldots+a_{m 2} y_{m} \geq c_{2} \\
a_{1 n} y_{1}+a_{2 n} y_{2}+a_{3 n} y_{3}+\ldots+a_{m n} y_{m} \geq c_{n} \\
y_{i} \geq 0, i=1 ; 2 ; m,
\end{gathered}
$$

where $y_{i}$ is the price for performing the work of i-type, currency units.

These two tasks are well known and paradigmatic, but clearly reflect the meaning and essence of the employee's wage/salary regardless of the form of the employer's enterprise $^{13}$.

Task 2 is double (dual) or conjugated to Task 1, which is called straight, starting or given to Task 2 .

The connection between the starting and dual tasks lies in the fact that the solution of one of these tasks can be obtained from the solution of another one.

A well developed tool for mathematical programming allows using computational procedures not only to elaborate the best plan, but also to make some meaningful economic conclusions based on the properties of the dual task.

The average wage under current conditions does not match moral or material expectations of employees. It is well known that the amount of one's wage in the Ukraine is the lowest in Europe. The share of wages in operating costs per unit of output is also low and does not meet the established European standards. In general, this rate in the industry of Ukraine is slightly higher than $9 \%$, which is three times lower than in the industries of the European countries. It is also appropriate to note that inter-sectoral wage differentiation up to 5.5 times - is unreasonable and contradicts the principle of compliance of an employee's wages with the level of his qualifications.

\section{CONCLUSIONS AND PROSPECTS FOR FURTHER RESEARCH IN THE FIELD}

The main functions of the state social policy during crisis are distributive and protective ones, i.e. they should guarantee a set of organizational legal and economic measures aimed at ensuring the well-being of every member of the society under specific economic conditions.

According to recent research, wages as the main component of labour income does not perform its essential functions, including insuring social security, as it remains very low.

Only sustainable economic growth can reduce poverty. However, poverty that results in primitive culture, poor education, training and ill health is a barrier to growth, espe-

\footnotetext{
${ }^{13}$ Matematicheskie metody optimizacii i jekonomicheskaja teorija [Mathematical methods of optimization and economic theory], translated by G.I. Zhukova, F.Ja. Kel'man, Ajris-press, Moscow 2002, p. 15.
} 
cially during the formation of a qualitatively new economy based on a humane, rational and efficient use of labour forces.

\section{REFERENCES}

[1] The concept of humanitarian development of Ukraine for the period until 2020,2011, available at: https //docs.google/ com/viewe?url=http //www.kultura.pl.ua/images/doks/ koncepciya_hum_rozvytku.pdf.

[2] Lazebna M.V., Quality of employment of people should be in the first place, "Rynok pratsi ta zajniatist' naselennia", 2013/3, p. 3.

[3] Vitlins'kyj V.V., Verchenko P.I., Analiz, modeliuvannia ta upravlinnia ekonomichnym ryzykom [Analysis, modelling and management of economic risk], KNEU, Kyiv 2000.

[4] Tytarenko T.M. , Zhyttievyj svit osobystosti u mezhakh $i$ za mezhamy budennosti [The life of an individual within and beyond ordinary], Lybid', Kyiv 2003.

[5] Apatova N.V., Formation of the vector of individual condition of an economic agent, "Sbornik nauchnikh trudov V Mezhdunarodnoj shkoly-simpoziuma AMUR" 2011, TNU im. V.I.Vernadskogo, Ukraine, p. 16.

[6] Kolot A.M., Sotsial'no-trudova sfera: stan vidnosyn, novi vyklyky, tendentsii rozvytku [Sociolabour sector: the state of relations, challenges and trends], Kyivs'kyj Natsional'nyj ekonomichnyy universytet im. V.Het'mana, Kyiv 2010.

[7] Yemel'ianenko L.M., Sotsial'no-ekonomichni dominanty liuds'koho $i$ tekhnolohichnoho rozvytku Ukrainy [Social and economic dominants of human and technological development of Ukraine], NAN Ukrainy, Kyiv 2009.

[8] Statistical Yearbook of Ukraine for 2012, Kyiv 2013.

[9] Zhadan O.V., Sotsial'no-trudovi vidnosyny v umovakh hlobalizatsii: teoriia i praktyka derzhavnoho rehuliuvannia [Socio-labour relations in the context of globalization: theory and practice of state regulation], Natsional'na akademija derzhavnoho upravlinnja pry Prezydentovi Ukrainy, Kharkivs'kyj rehional'nyj instytut derzhavnoho upravlinnia, Kharkiv 2012.

[10] Balanda A.L., Sotsial'ni determinanty natsional'noi bezpeky Ukrainy [Social determinants of national security of Ukraine], Instytut demohrafii ta sotsial'nykh doslidzhen', Kyiv 2008.

[11] Matematicheskie metody optimizacii i jekonomicheskaja teorija [Mathematical methods of optimization and economic theory], translated by G.I. Zhukova, F.Ja. Kel'man, Ajris-press, Moscow 2002.

[12] Honcharov V.M., Riabokon' M.V., Pozhydaiev A.Ye., Mekhanizm derzhavnoho rehuliuvannia sotsial'no-trudovykh vidnosyn [Mechanism of state regulation of socio-labour relations], Noulidzh, Luhans'k 2012.

[13] Libanova E.M., Palij E.M., Rynok pratsi ta sotsial'nyj zakhyst [Labour market and social security], Osnovy, Kyiv 2004.

[14] Liashenko I.M., Korobova I.M., Horitsyna I.A., Modeliuvannia ekonomichnykh, ekolohichnykh i sotsial'nykh protsesiv [Modelling of economic, environmental and social processes], Vydavnycho-polihrafichnyj tsentr „Kyivs'kyj universytet”, Kyiv 2010.

[15] Klebanova T.S., Dubrovina N.A., Poljakova O.Ju., Modelirovanie jekonomicheskoj dinamiki [Modelling of economic dynamics], $2^{\text {nd }}$ ed., Izdatel'skij dom ,INZhJeK”, Kharkiv 2005.

\section{СОВЕРШЕНСТВОВАНИЕ ФУНКЦИОНИРОВАНИЯ РЫНКА ТРУДА КАК СТРАТЕГИЧЕСКОГО ФАКТОРА ЭКОНОМИЧЕСКОГО РОСТА}

В статье акцентируется внимание на рынке труда Украины, значении трудовых ресурсов для экономического роста.

Исследовано влияние безработицы, которая в Украине является не только составляющей рыночной экономики, но и результатом влияния особых политических 
и экономических факторов. Раскрывается содержание исследований рынка труда на грани социальных, экономических и психологических аспектов. Использована методика по определению психоэмоционального состояния отдельной личности и модель валютной паники, по освещению психоэмоционального настроения социальной группы или общества в целом. При усилении поляризации в обществе становится насущной справедливость и защищенность населения, а спрос на труд как основной источник доходов является первоочередным желанием и задачей одновременно. Установлено, что согласно теории двойственности по математическому программированию, как способа уравновешивания отношений между работодателем и работником, совершенствования рынка труда является первоочередной, так математически задача согласно показателей официальной заработной платы и оценки профессиональных знаний и умений не имеет решения, не имеет общих точек. Следовательно национальная экономика должна развиваться согласно экономических законов, несмотря на что просматриваются диспропорции в национальной экономике, что население Украины заслуживает адекватной оценки своих знаний и умений, и, соответственно, иметь возможность реализовывать свои моральные и материальные потребности, Доказано, что важным стратегическим мероприятием социально экономической политики Украины является формирование качественно новой экономики, основой которой является гуманное, рациональное, эффективное использование трудовых ресурсов.

Ключевые слова: экономика, рост, трудовые ресурсы, теория двойственности

\section{DOI: 10.7862/rz.2014.mmr.36}

Tekst złożono w redakcji: lipiec 2014

Przyjęto do druku: wrzesień 2014 